\title{
New protoceratopsid specimens improve the age correlation of the Upper Cretaceous Gobi Desert strata
}

\author{
Łukasz Czepiński \\ Acta Palaeontologica Polonica 65 (3), 2020: 481-497 doi:https://doi.org/10.4202/app.00701.2019
}

New protoceratopsid (Dinosauria: Ceratopsia) specimens from two Late Cretaceous

Mongolian localities with problematic stratigraphy are described. A specimen of Protoceratops andrewsi from the Zamyn Khond locality enables its correlation with other sites of the Djadokhta Formation. $P$. andrewsi is also abundant in the Üüden Sair locality, variously assigned to the Djadokhta or Baruungoyot formations. However, one new specimen from that site exhibits a fused nasal horn and a sharp buccal crest of the dentary. With these apomorphic features, it resembles Bagaceratops rozhdestvenskyi, known from the Baruungoyot and Bayan Mandahu formations. It may be an evidence for: sympatric evolution of $B$. roz hdestvenskyi and $P$. andrewsi; a dispersal of Bagaceratops to Üüden Sair; hybridization between the two parapatric taxa; or the anagenetic evolutionary transition from $P$. andrewsi to Bagaceratops. The anagenetic explanation appears to be most strongly supported by given data. This new record advocates for the age of the sediments from the Üüden Sair locality being intermediate between the Djadokhta and Baruungoyot formations. The observed changes in the frequency of the apomorphic features within protoceratopsid samples from various Late Cretaceous sites of the Gobi Desert potentially enable their correlations and chronological ordering.

Key words: Dinosauria, Ceratopsia, Protoceratopsidae, biostratigraphy, gradual evolution, anagenesis, Mesozoic, Mongolia.

Łukasz Czepiński [lczepinski@biol.uw.edu.pl, ORCID: https://orcid.org/0000-0002-8621-3888], Department of Palaeobiology and Evolution, Faculty of Biology, Biological and Chemical Research Centre, University of Warsaw, Żwirki i Wigury 101, 02-089 Warszawa, Poland.

This is an open-access article distributed under the terms of the Creative Commons Attribution License (for details please see creativecommons.org), which permits unrestricted use, distribution, and reproduction in any medium, provided the original author and source are credited. 
For 5 Full text $(31,832.5 \mathrm{kB})$

POFF' Supplementary file $(90.9 \mathrm{kB})$ 